\title{
11. An information systems design theory for an RFID university-based laboratory
}

\author{
SAMUEL FOSSO WAMBA \\ ÉCOLE POLYTECHNIQUE DE MONTRÉAL, AND \\ UNIVERSITY OF WOLLONGONG
}

\author{
KATINA MICHAEL \\ UNIVERSITY OF WOLLONGONG
}

\section{Abstract}

Radio frequency identification (RFID) technology is defined as a wireless automatic identification and data capture (AIDC) technology and is considered 'the next big thing' and 'the next revolution' in the management of the supply chain. Recently, the topic has attracted the interest of the industrial community as well as the scientific community. Following this tendency, this chapter applies an information systems design theory (ISDT) to an RFID-based university laboratory. For practitioners, the chapter provides some insights into the set-up and use of an RFID laboratory in university settings and, at the same time, offers a set of hypotheses that can be empirically tested.

\section{Introduction}

It has been stated that radio frequency identification (RFID) technology is one of the 'most pervasive computing technologies in history' (Roberts 2006:18). In the context of management, the technology has been viewed as 'the next big thing' (Wyld 2006:154) and 'the next revolution in the supply chain' (Srivastava 2004:1) since it allows 'any tagged entity to become a mobile, intelligent, communicating component of the organization's overall information 
infrastructure' (Curtin et al. 2007:88). The concept behind RFID is, however, not new. Indeed, it was used for the first time during World War II by the British Air Force to differentiate Allied from enemy aircraft.

Though the high potential of RFID technology in terms of operational performance optimisation is obvious, some key questions remain. For example: how should an appropriate business case be constructed? What is the impact on the firm when RFID is used with only a portion of one's trading partners? Will RFID have similar impacts inside and outside an organisation? In the same light, it is worth knowing what considerations are to be taken into account at the industry level, what factors are conducive to the adoption of RFID by a firm and whether in an inter-organisational context or internationally. Other issues are whether traditional IT adoption research paradigms are appropriate and if new performance measurement approaches are required to realise value from RFID; how a firm can make efficient use of real-time item/operator entity RFID tag placement, as well as real-time systems-based decision making. Moreover, one can ask how RFID and real-time decision making will change managerial capabilities, who does the tagging, who owns the technology and the data, who gets the value, who pays for readers that benefit multiple parties and who drives the effort to build standards, and so on (Curtin et al. 2007). Contributing to this debate, many RFID university-based laboratories are emerging around the world. The complex nature of RFID systems, however, turns the set-up of any RFID university-based laboratory into a very challenging exercise, as it is timeconsuming and requires an appropriate choice of the various components of the system and support from various actors within the RFID industry. The process is even more challenging as there is no theoretical basis to provide assistance for universities in setting up such facilities. The objective of this chapter is to partially fill this gap by: 1) applying an information systems design theory (ISDT) to an RFID university-based laboratory; and 2) providing validation of our proposals.

The next section presents an overview of information systems design theories. Following this a literature review of RFID technology and a review of an RFID university-based laboratory are presented. In section four, an ISDT for an RFID university-based laboratory is proposed. Hypothesis testing appears in section five while the conclusion and future research feature are in section six.

\section{Information systems design theories}

ISDT is defined as 'a field of research concerned with the effective design, delivery, use and impact of information technology in organizations and society' (Jones et al. 2003:1). ISDT is concerned with the design of artefacts and their 
use in human-machine systems and involves theory and practice to achieve these goals (Gregor 2002; Markus et al. 2002; Martin 2004). The goal-oriented perspective of ISDT has created a rising interest in designing theories within the IS community (Goldkuhl 2004) as it enables them to draw theory from best practices at operational, management or strategic levels (Martin 2004).

As shown in Table 11.1, we can distinguish five types of theory: 1) analytical and descriptive theory; 2) theory for understanding; 3) prediction theory; 4) explanatory and predictive theory; and 5) theory for design and action (Gregor 2006; Jones et. al. 2003).

Table 11.1 Types of theory

\begin{tabular}{|c|c|c|}
\hline Type & Question & Example of study \\
\hline Analysing and describing & What is? & Bapna et al. (2004) \\
\hline Understanding & How and why? & Levina and Ross (2003) \\
\hline Predicting & What will be? & Bapna et al. (2003) \\
\hline Explaining and predicting & $\begin{array}{l}\text { What? How? Why? What will } \\
\text { be? }\end{array}$ & Subramani (2004) \\
\hline Design and action & How to do something? & Fan et al. (2003) \\
\hline
\end{tabular}

Sources: Gregor (2006); Jones et al. (2003).

ISDT, which is the one used in this chapter, is considered part of the theory for design and action (Gregor 2002; Jones et. al. 2003). It is concerned with how to design the artefact and the design process (Kourouthanassis 2006; Walls et al. 2004), which are components of ISDT (Table 11.2). The design product comprises: 1) the meta-requirements used to deal with a class of problems or goals to which the theory applies (Siponen et al. 2006); 2) meta-design principles, which describe a class of artefacts hypothesised to meet the metarequirements; 3) kernel theories, which are relevant theories derived from natural or social sciences governing design requirements; and 4) testable design product hypotheses, which are used to validate the match between the artefact outcome and the meta-design. The other aspect of an ISDT is the design process and it involves: 1) a design method, which describes all procedures used for artefact construction; 2) kernel theories similar to, or different from, those being used in designing the product; and 3) testable design process hypotheses that can be used to ascertain that the design method results match the meta-design (Siponen et al. 2006; Walls et al. 2004). 
Information Systems Foundations: The Role of Design Science

Table 11.2 Components of an information system design theory

\begin{tabular}{|l|l|}
\hline \multicolumn{1}{|c|}{ 1. Meta-requirements } & Describes the class of goals to which the theory applies \\
\hline 2. Meta-design & $\begin{array}{l}\text { Describes a class of artefacts hypothesised to meet the meta- } \\
\text { requirements }\end{array}$ \\
\hline 3. Kernel theories & $\begin{array}{l}\text { Theories from natural or social sciences governing design } \\
\text { requirements }\end{array}$ \\
\hline $\begin{array}{l}\text { 4. Testable design product } \\
\text { hypotheses }\end{array}$ & $\begin{array}{l}\text { Used to test whether the meta-design hypotheses meet the } \\
\text { meta-requirements }\end{array}$ \\
\hline & \multicolumn{1}{|c|}{ Design process } \\
\hline 1. Design method & $\begin{array}{l}\text { A description of procedure(s) for artefact construction } \\
\text { process itself }\end{array}$ \\
\hline 2. Kernel theories & $\begin{array}{l}\text { Used to verify whether the results of the design hypothesis- } \\
\text { based method in an artefact are consistent with the meta- } \\
\text { design }\end{array}$ \\
\hline $\begin{array}{l}\text { 3. Testable design procest } \\
\text { hypotheses }\end{array}$
\end{tabular}

Source: Walls et al. (2004)

In addition, ISDT can involve the methodologies, guidelines, principles or tools that are used in the development of the artefacts (Gregor 2002), in order to accelerate the design process by restricting available options and thus reducing developers' uncertainty and leading to better development results (Markus et al. 2002). Furthermore, ISDT allows researchers to generate testable research hypotheses that can be empirically validated using both positivistic and interpretative research methods (Markus et al. 2002; Siponen et al. 2006). More precisely, ISDT draws on three interconnected elements - namely: 1) a set of user requirements; 2) a set of principles for selecting system features; and 3) a set of principles deemed effective for guiding the development process. Also, ISDT is based on a theory, which is also referred to as kernel theory, and provides more practical implementation methods to practitioners (Gregor 2002; Markus et al. 2002).

Many researchers have already used the components of an ISDT proposed by (Walls et al. 2004:Table 2) for emerging technologies (Jones et al. 2003; Kourouthanassis 2006; Markus et al. 2002; Siponen et al. 2006). Our study follows this trend and applies an ISDT for one RFID university-based laboratory. 


\section{RFID technology and RFID university-based laboratory}

\section{RFID technology as an emerging inter-organisational information system}

RFID technology is an emerging inter-organisational information system (IOS) that uses radio frequencies to automatically identify individual items or products in real time in a given supply chain (Curtin et al. 2007; Poirier and McCollum 2006). It belongs to two main classes of technologies: 1) automatic identification and data capture (AIDC) technologies, such as barcodes, biometrics and magnetic stripes; and 2) wireless technologies such as local area networks and metropolitan area networks (for more details, see Fosso Wamba et al. 2008a).

\section{RFID technology components}

Any RFID system is a combination of three major technologies: 1) a tag - active, passive or semi-passive - which serves as an electronic source of data and can be attached to or embedded in a physical object to be identified; 2) a reader and its antennas that communicate with the tag without requiring line of sight; and 3) a host server equipped with software (middleware) that manages the RFID system, filters data and interacts with enterprise applications. The middleware is the backbone of any RFID system. Indeed, it is the place where all business decisions that are used to manage the entire RFID system are configured (Fosso Wamba et al. 2008b).

RFID tags have various sizes and functional characteristics; however, the most important are the following.

1. Power source: an active tag contains a tiny battery from which power is drawn, while a passive tag does not contain any power source. The semipassive tag works as a passive tag, but has a power source that enables it to run an onboard sensor (Roberti 2006a).

2. Operating frequency: the low-frequency tag uses frequencies ranging from 125-134 kHz, the high-frequency tag uses the $13.56 \mathrm{MHz}$ frequency, the ultra-high-frequency tag uses a frequency between 866 and $960 \mathrm{MHz}$, and the microwave tag works with frequencies ranging from 2.4 to $5.8 \mathrm{GHz}$.

3. Read range. 
4. Data storage capacity and capability: the RFID tag can be either read only or read/write. The data transmission rates of active tags are higher than those of passive tags and, similarly, the data storage capacity of the latter is smaller than that of the former.

5. Operational life: owing to its power source, the active tag's operational life is shorter than that of the passive tag (depending on how the power source is being used).

6. Cost: as it lacks a power source, the passive tag is less expensive than the active tag (Asif and Mandviwalla 2005).

It should be noted that RFID readers: 1) can have a read or read/write capability (Ngai et al. 2007), which enables data to be read or read/written on RFID tags through radio frequencies when these tags are passed near the range of the reader; 2) can be configured to control the timing communication with the RFID tag (the reader talks first) or to react to messages from the tags (the tag talks first) (Asif and Mandviwalla 2005); and 3) can be a fixed or a mobile device.

\section{RFID technology capability}

RFID technology is capable of delivering precise and accurate data from any tagged products (at item, case or palette levels) in real time in a given supply chain, thus increasing information flow (Datta et al. 2007; Fosso Wamba and Boeck 2008; Riggins and Slaughter 2006) as well as improving supply-chain efficiency (Katina and Luke 2005; Loebbecke 2007). Moreover, the technology is 'expected to revolutionize many of the collaborative supply chain processes and to empower new collaboration scenarios, such as anti-counterfeiting, product recall and reverse logistics, collaborative in-store promotion management and total inventory management' (Bardaki et al. 2007:1). For example, when adapted to specific context, RFID technology allows a vast range of applications such as inventory management, access control, anti-counterfeiting, logistical tracking, and so on.

Despite its high potential, RFID technology is currently facing many problems that prevent its large-scale adoption. Among these problems are issues of standards, changing RFID middleware options, tag and reader performance (Riggins and Slaughter 2006), the lack of investment returns (Vijayaraman and Osyk 2006) and the requirement in terms of strategy redesign, business process redesign, IT infrastructure transformation and organisational structural transformation (Fosso Wamba et al. 2008a). These issues have led to the establishment of many RFID-based university laboratories, each of which is working on a specific area in order to provide some possible answers (Table 11.3). 
Table 11.3 Some RFID university-based laboratories

\begin{tabular}{|c|c|c|}
\hline University RFID lab & Purpose & Source \\
\hline $\begin{array}{l}\text { Auto-ID Labs } \\
\text { 1. MIT, 2. University of } \\
\text { Cambridge, 3. University of } \\
\text { St Gallen, 4. University of } \\
\text { Fudan, 5. Information and } \\
\text { Communication University, } 6 . \\
\text { University of Adelaide, and } 7 . \\
\text { Keio University }\end{array}$ & $\begin{array}{l}\text { Creating internet networks for things } \\
\text { using RFID and wireless sensor networks } \\
\text { Creating a global system for tracking } \\
\text { goods using a single-numbering system } \\
\text { called the electronic product code }\end{array}$ & Auto-ID Labs* \\
\hline $\begin{array}{l}\text { University of Nebraska- } \\
\text { Lincoln }\end{array}$ & $\begin{array}{l}\text { The university has an extensive RFID } \\
\text { lab stocked with RFID and material- } \\
\text { handling equipment that students use for } \\
\text { coursework } \\
\text { The course focuses on RFID, RFID in } \\
\text { logistics and RFID in engineering and } \\
\text { business classes }\end{array}$ & Burnell (2008) \\
\hline $\begin{array}{l}\text { Middlesex Community } \\
\text { College in Massachusetts }\end{array}$ & $\begin{array}{l}\text { Certificate program geared towards } \\
\text { preparing students to install and service } \\
\text { RFID equipment }\end{array}$ & Burnell (2008) \\
\hline $\begin{array}{l}\text { Boise State University and } \\
\text { the University of Alaska } \\
\text { Anchorage }\end{array}$ & $\begin{array}{l}\text { A joint graduate certificate program in } \\
\text { supply chain management with a strong } \\
\text { RFID focus }\end{array}$ & Burnell (2008) \\
\hline $\begin{array}{l}\text { Alien's RFID Solutions } \\
\text { Center (supported by five } \\
\text { universities: Ohio State } \\
\text { University, Ohio University } \\
\text { Center for Automatic } \\
\text { Identification, Wilberforce } \\
\text { University, Wright State } \\
\text { University and the University } \\
\text { of Cincinnati) }\end{array}$ & $\begin{array}{l}\text { Developing RFID curricula } \\
\text { Enhancing RFID studies via student } \\
\text { internships at the Solutions Center } \\
\text { Facilitating faculty consulting } \\
\text { engagements at the center and other } \\
\text { joint projects }\end{array}$ & Roberti (2006b) \\
\hline Oklahoma State University & $\begin{array}{l}\text { Course focusing on RFID system } \\
\text { applications in manufacturing and } \\
\text { engineering systems } \\
\text { A systematic statistical approach for } \\
\text { experimental design of a developed RFID } \\
\text { system. The research has yielded new } \\
\text { principles for harnessing information on } \\
\text { the complex (non-linear and stochastic) } \\
\text { nature of the process underlying signals } \\
\text { from RFID and other sensor networks }\end{array}$ & Burnell (2008) \\
\hline $\begin{array}{l}\text { Southern Alberta Institute of } \\
\text { Technology }\end{array}$ & $\begin{array}{l}\text { To foster innovation and to conduct } \\
\text { applied research in RFID application } \\
\text { technologies } \\
\text { This leading-edge facility allows local } \\
\text { and national enterprises from all sectors } \\
\text { to implement RFID applications in areas } \\
\text { such as supply-chain management, asset } \\
\text { tracking, safety systems and process } \\
\text { information analysis }\end{array}$ & SAIT (2008) \\
\hline
\end{tabular}




\begin{tabular}{|l|l|l|}
\hline University RFID lab & \multicolumn{1}{l|}{ Surpose } \\
\hline $\begin{array}{l}\text { Texas State Technical } \\
\text { College RFID Training Center }\end{array}$ & $\begin{array}{l}\text { Training facility for corporate and } \\
\text { student education in RFID } \\
\text { To provide state-of-the-art workforce } \\
\text { training } \\
\text { To serve as a centre of excellence } \\
\text { devoted to facilitating the widespread } \\
\text { adoption of RFID technologies }\end{array}$ & $\begin{array}{l}\text { TSTC Waco } \\
\text { (2008) }\end{array}$ \\
\hline University of Pittsburgh & $\begin{array}{l}\text { Serves as an international resource to } \\
\text { academics and members of the business } \\
\text { community }\end{array}$ & Mickle (2007) \\
\hline $\begin{array}{l}\text { ePoly Center at Polytechnic } \\
\text { School of Montreal }\end{array}$ & $\begin{array}{l}\text { Training facility for corporate and } \\
\text { student education in RFID } \\
\text { Course focused on RFID, RFID in } \\
\text { logistics and RFID in engineering and } \\
\text { business classes } \\
\text { Evaluation of the impacts of RFID/EPC } \\
\text { on supply-chain management in the } \\
\text { context of B2B } \\
\text { RFID project management }\end{array}$ & $\begin{array}{l}\text { Fosso Wamba } \\
\text { et al. (2008a, } \\
\text { 2008b) } \\
\text { (2007) }\end{array}$ \\
\hline $\begin{array}{l}\text { University of Wisconsin RFID } \\
\text { Lab }\end{array}$ & $\begin{array}{l}\text { Demonstration and education of RFID } \\
\text { technology and applications }\end{array}$ & Burnell (2008) \\
\hline University of Arkansas RFID & $\begin{array}{l}\text { To create and extend knowledge in RFID } \\
\text { utilisation and its impacts on business } \\
\text { and society }\end{array}$ & $\begin{array}{l}\text { RFID Research } \\
\text { Center (2008) }\end{array}$ \\
\hline
\end{tabular}

* From the Auto-ID Labs web site: <http://autoid.mit.edu/cs/>

\section{ISDT for an RFID university-based laboratory}

This section deals with ISDT when applied to an RFID university-based laboratory (Table 11.2). The various components of ISDT are described below.

\section{Meta-requirements}

There are four main meta-requirements

- the first refers to all technology providers and is necessary for the set-up and running of the RFID-based laboratory

- the second refers to the profile of potential RFID university-based laboratory users (for example, industrial stakeholders, students, policymakers)

- the third refers to the RFID university-based laboratory support for the various RFID applications using different contexts (for example, manufacturing, retailing, and so on) 
- the fourth is the ability of researchers working in the laboratory to quickly select RFID technology components and convert the requirements of potential users into decision rules to be implemented in the RFID middleware.

Regarding the set-up and the use of an RFID-based laboratory, the head of the research centre needs to create a network of all actors ranging from RFID technology providers (tag provider; reader provider; middleware provider and auxiliary RFID system provider of items such as stack lights, motion sensors, and so on; complementary software providers such as business process management system [BPMS] providers and enterprise resource planning [ERP] providers) to potential users (for example, students, industrial stakeholders).

Indeed, as any RFID system comprises three major technologies, the head of the RFID-based laboratory needs to establish a strong partnership with the firm involved in the design, testing and distribution of different RFID components. Through this partnership, the research centre could act as a bridge between all potential users and all RFID technology providers by putting together all pieces of equipment needed to test a specific application, by enabling potential users to test, learn and trial the technology and allowing the RFID technology providers to refine and adjust their offers to a potential RFID technology adopter. Moreover, the RFID-based laboratory could facilitate the creation of new partnerships between different RFID technology providers (tag provider with reader provider and middleware provider for a specific application), which leads to a bundled RFID system offer to potential customers. For example, some applications in the shipping industry could require RFID tags with higher frequencies for longer range, while RFID tags with low frequencies might be needed to access control applications (Asif and Mandviwalla 2005). To cope with the technological needs of potential users, the diversification issue has to be quickly addressed by the RFID-based laboratory through partnerships.

To be more efficient in this context, the head of an RFID-based laboratory needs to make some choice regarding specialisation. For instance, the University of Cambridge, which is part of the Auto-ID Labs, focuses on the integration of RFID and other identification technologies into industrial environments by developing specific research themes such as: 1) reduction in the uncertainty of RFID deployment; 2) methodologies for tracking and tracing objects; 3) management of product information networks; 4) quantification of the impact of RFID introduction; and 5) RFID integration with sensing and automation systems. ${ }^{1}$ On the other hand, the University of Arkansas RFID Research Center (Table 11.3) is trying to use the laboratory to create and extend knowledge in

1 From Cambridge Auto-ID Lab web site: <http://www.autoidlabs.org.uk/> 
RFID utilisation and its impacts on business and society. Specialisation could foster the development of RFID best practices by industry, sector and application, and thus enable comparisons through collaboration between laboratories.

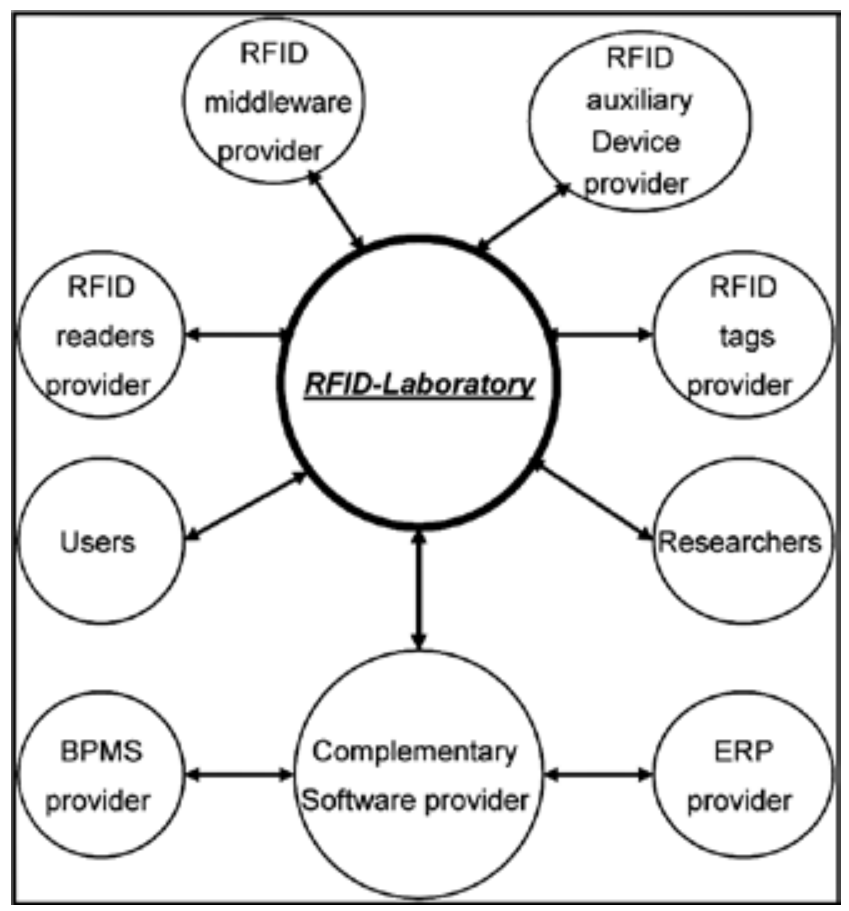

Figure 11.1 Potential stakeholders involved in the set-up and use of an RFID university-based laboratory

\section{Meta-design}

Researchers working in an RFID-based laboratory could be regarded as the designers or the integrators of the product artefact (RFID system). Indeed, they need to have the required knowledge to analyse users' needs, identify the required RFID system, install the system, test it and translate 'users' business requirements' into decision rules in the middleware. The key issue here is the designers' capacity to design a product artefact that is flexible enough to meet the various users' needs. For example, by using a motion sensor, designers could use the same gate equipped with an RFID reader to simulate a 'receiving process' (inbound) or a 'shipping process' (outbound) depending on the direction of the movement. Also, they could use BPMS to model and simulate different configurations of the RFID system in order to choose the optimal one. This could help accelerate and enhance the accuracy of component selection as 
well as the RFID system integration process. To achieve this, they need to rely on some basic communication quality so as to create fruitful exchanges with all RFID-based laboratory stakeholders.

\section{Kernel theories}

Given the emerging nature of RFID technology and the wish of stakeholders involved in the project to better understand the technology and assess its impact on their business processes, three theories that could apply to this ISDT have been identified

- business process re-engineering (BPR)

- IT business value and impacts

- IT diffusion theory.

Firms have been facing strong challenges such as market globalisation, aggressive competition, increasing cost pressures, the rise of customised demands with high product variance, the management of short shelf-life groceries and strict traceability requirements. In order to cope with all this, firms have been investing huge amounts of money in IT. These investments do not, however, always lead to improved organisational performance. This phenomenon is better known as the 'IT productivity paradox' (Brynjolfsson and Hitt 1996) and is due to the macroeconomic approach that is being used to assess the impact of IT investments (Oz 2005). Many authors call for the use of an alternative approach - known as the process-oriented approach - which emphasises the evaluation of IT investments at the locus of the impact: 'business process' (Zhu and Kraemer 2002).

'A business process is a set of interrelated activities which have definable inputs and, when executed, result in an output that adds value from a customer's perspective' (Al-Mudimigh 2007:869). BPR or business process management (BPM) aims to improve organisational performance in terms of cost, quality, service and speed (Hammer and Champy 1993; Ulbrich 2006). BPR is considered a key dimension in IT implementation (for example, ERP, integrated standard software packages and enterprise application systems). In fact, in order to grasp the real potential of an emerging IT, the current intra and inter-organisational business process needs to be redesigned before any implementation (AlMudimigh 2007). In the same light, Sarker and Lee (2002:10) state that 'IT is the central object of redesign in the redesign process'. Also, the transformational effects of IT investments need to be explored by taking into consideration the firm IT strategy, IT management capability and external environment and industry factors. IT diffusion theory offers important insights into the way in which, and the speed at which, an emerging technology is adopted by the members 
of a social system (Rogers 2003; Venkatesh et al. 2003) - by considering IT characteristics (for example, complexity, compatibility and relative advantage), organisations' characteristics and the factors that influence the adoption (for example, mandates, centralisation, organisational slack), diffusion process and contextual factors (for example, level of competitiveness, reputation, research and development allocation, technology standardisation) (Damanpour and Schneider 2006; Fichman 1992).

\section{Design method}

Many recent studies of RFID technology suggest that it is not a "plug and play technology' (Fosso Wamba et al. 2008b). To grasp its impacts on firm performance, the integrator needs to focus on the product value chain of the firm, critical activities within that product value chain and core business processes associated with these activities. Based on these prerequisites, the first design method should be focused on the intensive use of a BPMS in order to propose various business process scenarios integrating RFID technology. This could help RFID laboratory integrators to easily transform firm business requirements into 'virtual' RFID laboratory component selection, thus reducing the cost associated with the simulation of each application in the laboratory. The second design method focus implies that integrators need to design the RFID laboratory to be as flexible as possible in order to handle various core business processes from various industries.

\section{Testable design product and design process hypotheses}

Based on the proposed kernel theories of this ISDT, the following hypotheses have been formulated

- the RFID university-based laboratory offers a vendor an independent environment for the testing and validation of various scenarios integrating RFID technology (H1)

- the RFID university-based laboratory is a viable means to evaluate the impact of RFID technology on supply-chain process performance (H2)

- the RFID university-based laboratory contributes to accelerating the adoption decision of RFID technology among potential adopters (H3)

- the RFID university-based laboratory acts as an enabler of knowledge transfer among potential users or adopters (H4)

- the RFID university-based laboratory contributes to assessing the user perception of RFID technology complexity (H5). 
All these hypotheses can be empirically tested using positivistic and interpretative research methods (Markus et al. 2002; Siponen et al. 2006).

\section{Validation}

Our hypotheses have been tested in one RFID university-based laboratory (Figure 11.2). The laboratory uses components from various suppliers (Table 11.4).

On the left side of Figure 11.2, we have an RFID portal, including

- a photo eye (1) for automatic product detection and a trigger to activate two fixed antennas (2), allowing the antennas to be awakened and to transmit radio waves to a fixed reader (3) only where necessary

- the reader captures or updates the information written on the tags (4)

- a stack light (5) linked to the fixed reader allows the confirmation of the status of the readings as the products (or boxes) are passing on the conveyor belts (6).

On the right side of Figure 11.2 are

- an RFID portal (7) with four fixed antennas

- two photo eyes

- one fixed reader similar to those on the left side of Figure 11.2.

The third part of the laboratory comprises an ERP server provided by SAP (8d), two middleware servers where all the business rules are configured $(8 a, 8 b)$ and one BPMS server from IDS Scheer AG (8c).

The three screens on the walls (9) are provided by the research centre. All the information resulting from transactions is projected here, allowing participants to follow the information flow in real time, as each transaction is automatically performed.

In the context of supply-chain applications, the RFID portal on the left side of Figure 11.2 could be used as the supplier's shipping dock and the RFID portal on the right side of Figure 11.2 as the retailer receiving dock.

This laboratory has been used for teaching purposes and for supply-chain redesign integrating RFID technology in the retailing and utility industries, thus demonstrating its high flexibility and adaptability (H4).

Regarding teaching, the laboratory has been used for courses at the undergraduate and postgraduate levels. The use of the laboratory at the two 
levels involved the tagging of various products with different characteristics (bottle with water, oil or cream, product with metal, and so on), the testing of the reader's reliability based on the type of product and the orientation of antennas, and the analysis of data capture by the reader in the middleware. Moreover, postgraduate students were involved in the data-collection process and validation. They were also involved in the mapping of existing business processes and the mapping of various scenarios integrating RFID technology using the BPMS tool. This exercise helps to validate the feasibility of business redesign processes integrating RFID technology, to assess their business value at different points of the supply chain and their technological feasibility through iterative discussion with key industrial and technological respondents. Finally, postgraduate students were involved in the demonstration of the integration of information systems (ERP and middleware) and optimisation of business processes in the laboratory. This step demonstrates that the implementation of RFID in the supply chain seems possible in terms of business and according to a technological perspective (H2).

Almost one-third of the students who undertook master's degree programs dealing with RFID technology have chosen to carry out their final projects on this topic. In addition, four of these students have decided to continue their doctoral studies on RFID technology, which highlights the importance of an RFID-based laboratory as a powerful teaching tool.

The laboratory has enabled the actors involved in different supply chains under study to identify opportunities for the optimisation of this technology. At the same time, it has raised the complementary investment that is needed to achieve the potential of RFID technology (IT and warehouse infrastructures, upgrading, employee training and change in management) and the limits of this technology in their specific context (standards, IT integration, security) (H5). After these studies were conducted in the laboratory the actors involved in the retail supply chain decided to conduct a pilot study in their setting (H3), but those from the utility industry were reluctant to move forward with a pilot study in their field. Indeed, the integration of the RFID-based infrastructure in the utility environment calls for a major redesign of their current IT infrastructure and the adoption of a 'new IT layer' from a vendor different to their current, traditional IT vendor. One of the managers involved in the project said: 'We are going to wait for the RFID package from our current IT vendor, so we'll not have to add a new IT layer into our infrastructure, and thus avoid the problems of integration, interoperability and security' (H1). Finally, the results of these studies were presented during numerous conferences, published in leading journals or integrated in book chapters (H4). 


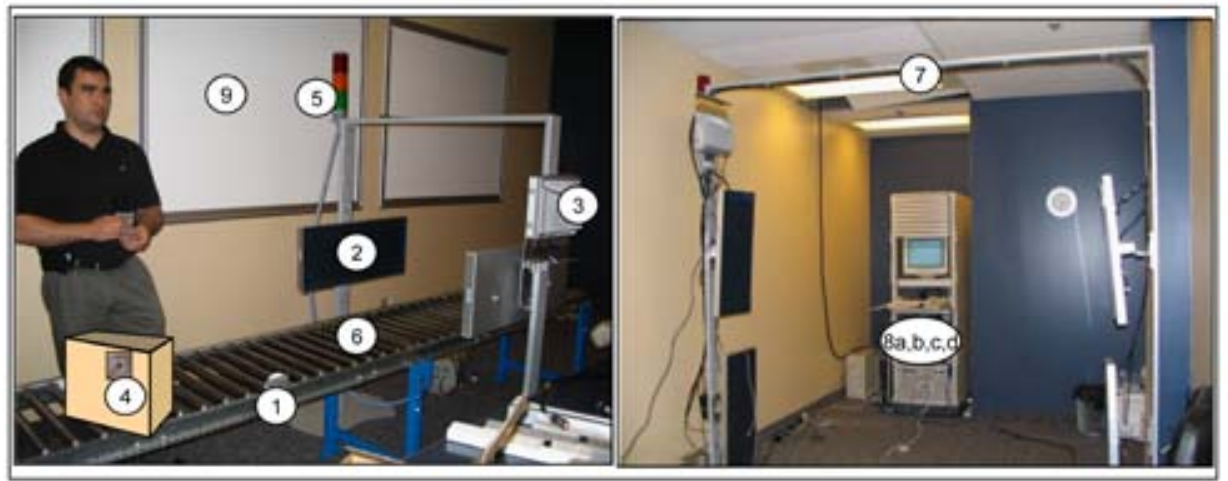

Figure 11.2 ePoly RFID Laboratory

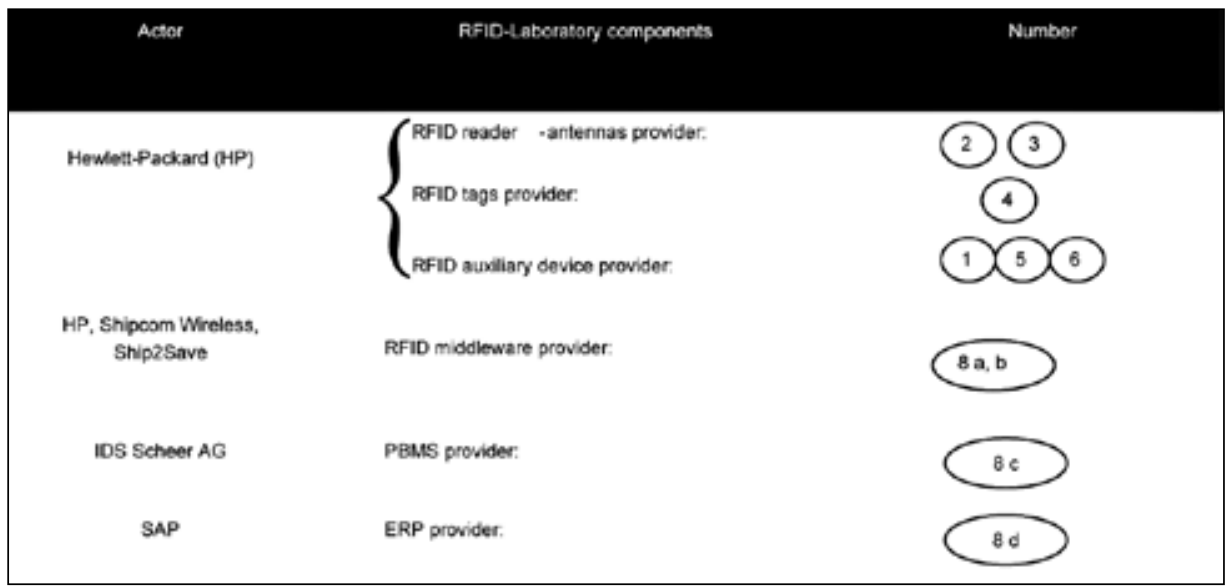

Table 11.4 Major suppliers of the ePoly RFID Laboratory equipment

\section{Conclusion}

In this chapter, an ISDT that is fit for the design, implementation and use of an RFID university-based laboratory is being used. The laboratory has been used for academic (teaching and research) and industrial (RFID application testing and validation) purposes. The study offers some insights into the set-up and use of an RFID-based laboratory in university settings and proposes a number of empirically testable hypotheses that are likely to be useful to researchers. The next logical step of this research work could be the validation of our hypotheses using empirical data from pilot studies conducted by firms involved in this study. Finally, in the context of the supply chain, RFID technology can also be considered an 'open innovation'. Indeed, to fully grasp the real value of RFID technology, we saw that members of the supply chain should establish co-development partnerships with various players in the RFID industry. In fact, 
co-development partnerships are viewed as 'increasingly effective means of innovating the business model to improve innovation effectiveness' (Chesbrough and Schwartz 2007:1).

\section{Acknowledgments}

This research has been made possible through the financial contribution of SSHRC, NSERC and FQRSC. We have benefited from the comments and suggestion of Dieudonné Toukam, MA. Also, the authors would like to thank the anonymous referee for his valuable input during the review process of the chapter.

\section{References}

Al-Mudimigh, A. S. 2007, 'The role and impact of business process management in enterprise systems implementation', Business Process Management Journal, vol. 13, no. 6, pp. 866-74.

Asif, Z. and Mandviwalla, M. 2005, 'Integrating the supply chain with RFID: a technical and business analysis', Communications of the Association for Information Systems, vol. 15, pp. 393-427.

Bapna, R., Goes, P. and Gupta, A. 2003, 'Replicating online Yankee auctions to analyze auctioneers' and bidders' strategies', Information Systems Research, vol. 14, no. 3, pp. 244-68.

Bapna, R., Goes, P., Gupta, A. and Jin, Y. 2004, 'User heterogeneity and its impact on electronic auction market design: an empirical exploration', MIS Quarterly, vol. 28, no. 1, pp. 21-43.

Bardaki, C., Pramatari, K. and Doukidis, G. I. 2007, 'RFID-enabled supply chain collaboration services in a networked retail business environment', 20th Bled eConference eMergence: Merging and Emerging Technologies, Processes, and Institutions, 4-6 June, Bled, Slovenia.

Bendavid, Y., Lefebvre, É., Lefebvre, L. A. and Fosso Wamba, S. 2007, 'B-to-B ECommerce: assessing the impacts of RFID technology in a five layer supply chain', Proceedings of HICSS, B-to-B E-Commerce Mini-Track, Computer Society Press, IEEE, Hawai'i. 
Brynjolfsson, E. and Hitt, L. M. 1996, 'Paradox lost? Firm-level evidence on the returns to information systems spending', Management Science, vol. 42, no. 4, pp. 541-58.

Burnell, J. 2008, 50+ RFID labs and test centers identified worldwide, <http:// www.rfidupdate.com/articles/index.php?id=1528>

Chesbrough, H. and Schwartz, K. 2007, 'Innovating business models with codevelopment partnerships', Research Technology Management, vol. 50, no. 1, pp. 55-9.

Curtin, J., Kauffman, R. J. and Riggins, F. J. 2007, 'Making the most out of RFID technology: a research agenda for the study of the adoption, usage and impact of RFID', Information Technology and Management, vol. 8, no. 2, pp. $87-110$.

Damanpour, F. and Schneider, M. 2006, 'Phases of the adoption of innovation in organizations: effects of environment, organization, and top managers', British Journal of Management, vol. 17, no. 3, pp. 215-36.

Datta, S., Granger, C. W. J, Barari, M. and Gibbs, T. 2007, 'Management of supply chain: an alternative modelling technique for forecasting', Journal of the Operational Research Society, vol. 58, pp. 1459-69.

Fan, M., Stallaert, J. and Whinston, A. B. 2003, 'Decentralized mechanism design for supply chain organization using an auction market', Information System Research, vol. 14, pp. 1-22.

Fichman, R. G. 1992, Information technology diffusion: a review of empirical research, Working Paper, MIT Sloan School of Management, Cambridge, Mass.

Fosso Wamba, S. and Boeck, H. 2008, 'Enhancing information flow in a retail supply chain using RFID and the EPC network: a proof-of-concept approach', Journal of Theoretical and Applied Electronic Commerce Research, Special Issue on RFID and Supply Chain Management, vol. 3, no. 1, pp. 93-105.

Fosso Wamba, S., Lefebvre, L. A., Bendavid, Y. and Lefebvre, É. 2008a, 'Exploring the impact of RFID and the EPC network on mobile B2B ECommerce: a case study in the retail industry', International Journal of Production Economics, Special Issue on RFID: Technology, Applications, and Impact on Business Operations, vol. 112, no. 2, pp. 614-29.

Fosso Wamba, S., Lefebvre, É., Bendavid, Y. and Lefebvre, L. A. 2008b, 'From automatic identification and data capture (AIDC) to "smart business process": 
preparing for a pilot integrating RFID', in Syed Ahson and Mohammad Ilyas (eds), RFID Handbook: Applications, technology, security, and privacy, CRC Press Taylor \& Francis Group, London.

Goldkuhl, G. 2004, 'Design theories in information systems - a need for multigrounding', Journal of Information Technology Theory and Application, vol. 6, no. 2, pp. 59-72.

Gregor, S. 2002, 'Design theory in information systems', Australian Journal of Information Systems, Special Issue, pp. 14-22.

Gregor, S. 2006, 'The nature of theory in information systems', MIS Quarterly, vol. 30, no. 3, pp. 611-42.

Hammer, M. and Champy, J. 1993, Reengineering the Corporation, Harper Business, New York.

Jones, D., Gregor, S. and Lynch, T. 2003, ‘An information systems design theory for web-based education', Proceedings of the IASTED International Symposium on Web-Based Education.

Katina, M. and Luke, M. 2005, 'The pros and cons of RFID in supply chain management', International Conference on Mobile Business (ICMB'05), pp. 623-629.

Kourouthanassis, P. E. 2006, A design theory for pervasive information systems, $<$ http://www.eltrun.aueb.gr/eltrun/phd-studies/completed-phds/phdthesis-title-a-design-theory-for-pervasive-information-systems-1/>

Levina, N. and Ross, J. W. 2003, 'From the vendor's perspective: exploring the value proposition in information technology outsourcing', MIS Quarterly, vol. 27, no. 3, pp. 331-364.

Loebbecke, C. 2007, 'Piloting RFID along the supply chain: a case analysis', Electronic Markets, vol. 17, no. 1, pp. 29-38.

Markus, M. L., Majchrzak, A. and Gasser, L. 2002, 'A design theory for systems that support emergent knowledge processes', MIS Quarterly, vol. 26, pp. 179-212.

Martin, A. 2004, Addressing the gap between theory and practice: IT project design', Journal of Information Technology Theory and Application, vol. 6, no. 2, pp. 23-42.

Mickle, M. H. 2007, 'Establishment of the University of Pittsburgh RFID Center of Excellence', IEEE Applications and Practice Magazine, vol. 45, no. 4, pp. 14-16. 
Ngai, E. W. T., Cheng, T. C. E., Au, S. and Lai, K.-H. 2007, 'Mobile commerce integrated with RFID technology in a container depot', Decision Support Systems, vol. 43, no. 1, pp. 62-76.

Oz, E. 2005, 'Information technology productivity: in search of a definite observation', Information \& Management, vol. 42, pp. 789-98.

Poirier, C. and McCollum, D. 2006, RFID Strategic Implementation and ROI: A practical roadmap to success, J. Ross Publishing, Fort Lauderdale, Fla.

RFID Research Center 2008, Mission, vision, history, <http://itri.uark.edu/118. asp>

Riggins, F. J. and Slaughter, K. T. 2006, 'The role of collective mental models in IOS adoption: opening the black box of rationality in RFID deployment', Proceedings of the 39th Hawaii International Conference on System Sciences.

Roberti, M. 2006a, 'Sensing new RFID opportunities', RFIDJournal, <http:// www.rfidjournal.com/article/articleview/2081/>

Roberti, M. 2006b, 'Alien opens Dayton RFID Lab', <http://www.rfidjournal. com/article/view/2140/1/1>

Roberts, C. M. 2006, 'Radio frequency identification (RFID)', Computers \& Security, vol. 25, no. 1, pp. 18-26.

Rogers, E. M. 2003, Diffusion of Innovations, The Free Press, New York.

SAIT 2008, New applications for radio frequency identification to be developed in SAIT's 'RAD Lab', <http://www.sait.ca/pages/research/index.shtml>

Sarker, S. and Lee, A. S. 2002, 'Using a positivist case research methodology to test three competing theories-in-use of business process redesign', Journal of the Association for Information Systems, vol. 2, no. 7, pp. 1-72.

Siponen, M., Baskerville, R. and Heikka, J. 2006, 'A design theory for secure information systems design methods', Journal of the Association for Information Systems, vol. 7, no. 11, pp. 725-70.

Srivastava, B. 2004, 'Radio frequency ID technology: the next revolution in SCM', Business Horizons, vol. 47, no. 6, pp. 60-8.

Subramani, M. R. 2004, 'How do suppliers benefit from information technology use in supply chain relationship?', MIS Quarterly, vol. 28, pp. 45-73.

TSTC Waco 2008, TSTC Waco receives \$305 000 for RFID training facility, $<$ http://www.waco.tstc.edu/ct/> 
Ulbrich, F. 2006, 'Improving shared service implementation: adopting lessons from the BPR movement', Business Process Management Journal, vol. 12, no. 2, pp. 191-205.

Venkatesh, V., Morris, M. G., Davis, G. B. and Davis, F. D. 2003, 'User acceptance of information technology: toward a unified view', MIS Quarterly, vol. 27, no. 3, pp. 425-78.

Vijayaraman, B. S. and Osyk, B. A. 2006, 'An empirical study of RFID implementation in the warehousing industry', The International Journal of Logistics Management, vol. 17, no. 1, pp. 6-20.

Walls, J. G., Widmeyer, G. R. and El Sawy, O. 1992, 'Building an information system design theory for vigilant EIS', Information Systems Research, vol. 3, no. 1, pp. 36-59.

Walls, J. G., Widmeyer, G. R. and El Sawy, O. A. 2004, 'Assessing information system design theory in perspective: how useful was our 1992 initial rendition?', Journal of Information Technology Theory and Application, vol. 6, no. 2, pp. 43-58.

Wyld, D. C. 2006, 'RFID 101: the next big thing for management', Management Research News, vol. 29, no. 4, pp. 154-73.

Zhu, K. and Kraemer, K. L. 2002, 'E-commerce Metrics for net-enhanced organizations: assessing the value of e-commerce to firm performance in the manufacturing sector', Information Systems Research, vol. 13, no. 3, pp. 275-95. 